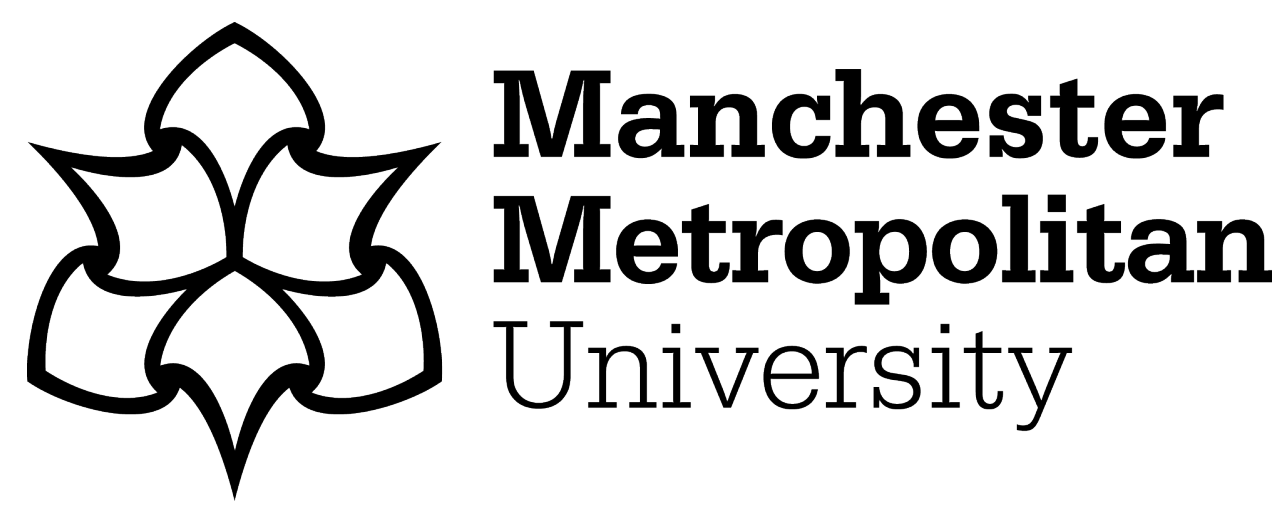

Ellison, Mark ORCID logoORCID: https://orcid.org/0000-0002-9019-6582, Pollock, Gary ORCID logoORCID: https://orcid.org/0000-0001-6673-2368 and Grimm, Robert (2020) Young People's Orientations Towards Contemporary Politics: Trust, Representation and Participation. Zeitschrift für Erziehungswissenschaft, 23 (6). pp. 1201-1226. ISSN 1434-663X

Downloaded from: https://e-space.mmu.ac.uk/626895/

Version: Accepted Version

Publisher: Springer Verlag

DOI: https://doi.org/10.1007/s11618-020-00984-4

Please cite the published version 


\section{Metadata of the article that will be visualized online}

\begin{tabular}{|c|c|c|}
\hline Article Title & \multicolumn{2}{|c|}{$\begin{array}{l}\text { Young people's orientations towards contemporary politics: Trust, representation and } \\
\text { participation }\end{array}$} \\
\hline Journal Name & \multicolumn{2}{|c|}{ Zeitschrift für Erziehungswissenschaft } \\
\hline CopyrightHolder & \multicolumn{2}{|c|}{$\begin{array}{l}\text { The Editors of the Journal } \\
\text { (This will be the copyright line in the final PDF) }\end{array}$} \\
\hline \multirow{7}{*}{$\begin{array}{l}\text { Corresponding } \\
\text { Author }\end{array}$} & Family name: & Ellison \\
\hline & Particle: & \\
\hline & GivenName: & Mark \\
\hline & Suffix: & \\
\hline & Organization: & Manchester Metropolitan University \\
\hline & Address: & M15 6LL Manchester, UK \\
\hline & Email: & m.ellison@mmu.ac.uk \\
\hline \multirow[t]{7}{*}{ Author } & Family name: & Pollock \\
\hline & Particle: & \\
\hline & GivenName: & Gary \\
\hline & Suffix: & \\
\hline & Organization: & Manchester Metropolitan University \\
\hline & Address: & M15 6LL Manchester, UK \\
\hline & Email: & g.pollock@mmu.ac.uk \\
\hline \multirow[t]{6}{*}{ Author } & Family name: & Grimm \\
\hline & Particle: & \\
\hline & GivenName: & Robert \\
\hline & Suffix: & \\
\hline & Organization: & Ipsos \\
\hline & Address: & Paris, France \\
\hline \multirow[t]{4}{*}{ Schedule } & Received: & 7 January 2020 \\
\hline & Revised: & 17 July 2020 \\
\hline & Accepted: & 19 October 2020 \\
\hline & \multicolumn{2}{|c|}{ Published online: } \\
\hline
\end{tabular}

Abstract Over the last thirty years voter turnout in elections at both national and European levels has in many countries fallen albeit with some notable increases in the most recent years. This, together with a decline in the perception of political efficacy and falling trust in political institutions, has been argued to have resulted in a democratic deficit (Norris 2011). Drawing on original data from thirty research locations in fourteen European countries as part of the MYPLACE (Memory, Youth, Political Legacy and Civic Engagement) project we explore young people's attitudes towards politics and their political behaviour. Our research confirms findings in existing literature: many young people feel that their political system is not working for them. Our results show that many young people harbour deep-seated cynicism towards the political class and tend not to trust political institutions including parliament and political parties. We also demonstrate, however, that the majority of young people are, in fact, interested in politics. Moreover, young people tend to support democracy as a political system. They also continue to perceive voting as the most effective form of participation. That a considerable number of young people are not actively participating in political processes is at odds with their professed beliefs. This paper contributes to understanding the contemporary political orientation of young people by exploring both their attitudes and behaviour. 
Zusammenfassung In den vergangenen dreißig Jahren ist die Wahlbeteiligung junger Bürger in nationalen und europäischen Wahlen kontinuierlich gefallen. Kürzliche Ausnahmen bestätigen die Regel. Abnehmende politische Effizienz und fallendes Vertrauen in Institutionen resultierten in einem demokratischen Defizit (Norris 2011). Basierend auf quantitative Primärdaten aus dreißig Regionen in vierzehn europäischen Ländern untersuchen wir das Interesse, die Einstellungen und Meinungen junger Menschen zu Politik und ihr Handeln bzw. ihre aktive Teilhabe an politischen Prozessen. Die Daten wurden als Teil des MYPLACE (Memory, Youth, Political Legacy and Civic Engagement) Projekts erhoben.

Unsere Forschung bestätigt die in bestehender Literatur dargestellten Ergebnisse: viele junge Menschen glauben, dass ihre Interessen durch das politische System nicht vertreten werden. Sie hegen einen tiefen Zynismus gegenüber der politischen Klasse und tendieren dazu, politischen Institutionen, Parlamenten und Parteien nicht zu vertrauen. Aber unsere Daten zeigen auch, dass trotz dieses Misstrauens, ein Großteil junger Menschen sich durchaus für Politik interessiert und sich positiv für die Demokratie als politisches System ausspricht. Auch sehen die meisten von ihnen demokratische Wahlen als die effizienteste Form der Partizipation und Mitgestaltung. Diese positive Grundeinstellung steht im Widerspruch zur aktiven Beteiligung junger Menschen an politischen Prozessen. Dieser Beitrag trägt zum gegenwärtigen Verständnis politischen Verhaltens und den Einstellungen junger Menschen in Europa bei.

Keywords sepa- Democracy - Politics - Political efficacy - Political participation - Young people rated by '-'

Keywords sepa- Politische Partizipation - Demokratie - Europa - Jugendforschung - Vertrauen rated by '-'

Please note: Images appear in color online but will be printed in black and white 


\title{
Young people's orientations towards contemporary politics: Trust, representation and participation
}

\author{
Mark Ellison (iD · Gary Pollock • Robert Grimm
}

Received: 7 January 2020 / Revised: 17 July 2020 / Accepted: 19 October 2020

(C) The Editors of the Journal

\begin{abstract}
Over the last thirty years voter turnout in elections at both national and European levels has in many countries fallen albeit with some notable increases in the most recent years. This, together with a decline in the perception of political efficacy and falling trust in political institutions, has been argued to have resulted in a democratic deficitl'(Norris 2011). Drawing on original data from thirty research locations in fourteen European countries as part of the MYPLACE (Memory, Youth, Political Legacy and Civic Engagement) project we explore young people's attitudes towards politics and their political behaviour. Our research confirms findings in existing literature: many young people feel that their political system is not working for them. Our results show that many young people harbour deep-seated cynicism towards the political class and tend not to trust political institutions including parliament and political parties. We also demonstrate, however, that the majority of young people are, in fact, interested in politics. Moreover, young people tend to support democracy as a political system. They also continue to perceive voting as the most effective form of participation. That a considerable number of young people are not actively participating in political processes is at odds with their professed beliefs. This paper contributes to understanding the contemporary political orientation of young people by exploring both their attitudes and behaviour.
\end{abstract}

Keywords Democracy $\cdot$ Politics $\cdot$ Political efficacy $\cdot$ Political participation $\cdot$ Young people

\footnotetext{
M. Ellison $(\bowtie) \cdot$ Prof. G. Pollock

Manchester Metropolitan University, Manchester, M15 6LL, UK

E-Mail: m.ellison@mmu.ac.uk

Prof. G. Pollock

E-Mail: g.pollock@mmu.ac.uk

Dr. R. Grimm

Ipsos, Paris, France
} 


\section{Einstellungen junger Menschen zur Politik: Vertrauen, Wahrnehmung und Partizipation}

Zusammenfassung In den vergangenen dreißig Jahren ist die Wahlbeteiligung junger Bürger in nationalen und europäischen Wahlen kontinuierlich gefallen. Kürzliche Ausnahmen bestätigen die Regel. Abnehmende politische Effizienz und fallendes Vertrauen in Institutionen resultierten in einem demokratischen Defizit (Norris 2011). Basierend auf quantitative Primärdaten aus dreißig Regionen in vierzehn europäischen Ländern untersuchen wir das Interesse, die Einstellungen und Meinungen junger Menschen zu Politik und ihr Handeln bzw. ihre aktive Teilhabe an politischen Prozessen. Die Daten wurden als Teil des MYPLACE (Memory, Youth, Political Legacy and Civic Engagement) Projekts erhoben.

Unsere Forschung bestätigt die in bestehender Literatur dargestellten Ergebnisse: viele junge Menschen glauben, dass ihre Interessen durch das politische System nicht vertreten werden. Sie hegen einen tiefen Zynismus gegenüber der politischen Klasse und tendieren dazu, politischen Institutionen, Parlamenten und Parteien nicht $\mathrm{zu}$ vertrauen. Aber unsere Daten zeigen auch, dass trotz dieses Misstrauens, ein Großteil junger Menschen sich durchaus für Politik interessiert und sich positiv für die Demokratie als politisches System ausspricht. Auch sehen die meisten von ihnen demokratische Wahlen als die effizienteste Form der Partizipation und Mitgestaltung. Diese positive Grundeinstellung steht im Widerspruch zur aktiven Beteiligung junger Menschen an politischen Prozessen. Dieser Beitrag trägt zum gegenwärtigen Verständnis politischen Verhaltens und den Einstellungen junger Menschen in Europa bei.

Schlüsselwörter Politische Partizipation · Demokratie · Europa ·

Jugendforschung · Vertrauen

\section{Introduction}

Political participation takes many forms (Verba and Nie 1972) including voting in elections, non-electoral participation and protest action, and is shaped by demographics (Marien et al. 2010), democratic performance (Norris 2011) and political socialisation (Sigel 1965). Formal types of participation including voter turnout in elections at both national and European levels has in many countries fallen over the last thirty years, though there are indications that this is starting to reverse (Politico 2019). This trend is particularly pronounced among young voters (Fieldhouse et al. 2007; Sloam and Henn 2019) with studies suggesting that recent generations of young people are least likely to either vote (Kimberlee 2002; Wattenberg 2006) or to participate in formal political organisations such as political parties and trade unions (Dalton and Wattenberg 2000). However, young people who are either too young to vote or wish to participate through broader political expressions (Pilkington and Pollock 2015), do so via non-electoral forms of participation and protest action (Stockemer 2014). Democracy, or 'government by the people' implies participation by the people (Coppedge et al. 2011; Lijphart 2012). A functioning democracy pre- 
supposes broad participation of citizens in the political process. Falling participation, together with a decline in the perception of political efficacy and falling trust in political institutions, has been argued to have resulted in a 'democratic deficit' (Norris 2011). Arguably, the growing democratic deficit has in recent years contributed to increased levels of political volatility as evidenced by the emergence of new political parties who have made quick gains in many European countries.

This paper draws on original data from 30 research locations in fourteen European countries as part of the European Commission funded Framework Seven Research Project Memory, Youth, Political Legacy and Civic Engagement (MYPLACE). A common survey instrument was administered face to face to respondents who were aged 16 to 25 at the time of the study in 2012/13. Utilising these data, we explore how young people's attitudes towards politics and their political behaviour varies across our study sites and European countries. Deploying multilevel regression analyses, we examine how factors including demographics, political socialisation and perceived democratic performance act as both enablers and barriers to a young person's political participation. The paper is structured as follows, first, we present a summary of the theoretical framework and the development of our hypotheses; second, we describe our data and the methods employed; third, we present our results before discussing results and conclusions.

\section{Theoretical framework}

\subsection{Political participation}

Participation is a broad umbrella term and despite the attention it has been given by social science scholars, there is no agreed definition. A number of definitions focus on the process of 'society shaping'. For instance, the Youth Partnership (2014l, p. 1) define participation as 'involvement and engagement of people in decision making and shaping of their living conditions'. Vromen (2003, p. 82f.) defines participation as 'acts that can occur, either individually or collectively, that are intrinsically concerned with shaping the society that we want to live in'.

Within participation, a distinction needs to be made between a narrow interpretation of politics (Furlong and Cartmel 2012) as traditional, institutionalised, conventional or direct forms of participation, such as voting and membership, and broader political expressions (Pilkington and Pollock 2015) including non-institutionalised or indirect forms of participation. Henn and Foard (2012, p. 65) suggest that "today's generation of young people are interested in political affairs, and they are keen to play a more active role in the political process". Young people want to engage in politics, but less so in traditional party politics (Norris 1999, 2002). Noninstitutionalised forms of political participation allow young people to participate at the same time keeping "some distance from the political system by trying to have an indirect impact on political decision-making or by circumventing the political system all together" (Marien et al. 2010, p. 189). This type of participation requires less commitment and it is possible to opt-out at any point (Li and Marsh 2008; Trechsel 2007). Young people often now choose to participate in less professionalised and 
controlled political activities such as in online forms of participation (Norris 2001), political consumerism (Stolle et al. 2005) or non-institutionalised activities in general (Norris 2003), leading to a diversification of political activities which young people participate in. Over the past decades, there has been a move from collective forms of participation to more individual forms, which mirrors theories around postmaterialism and individualisation (Inglehart 1977). Perhaps the various climate related activities taking place across the world during 2019, notable for its inclusion of school children taking time off on Fridays to demonstrate (\#Fridaysforthefuture), inspired by the Swedish activist Greta Thurnberg, shows these tendencies to have become more strongly embedded.

Political Participation together with civic engagement (Berger 2009) are complex, intertwined and evolving as new means of participation appear. Scholars have made various attempted to develop typologies of participation (Berger 2009; Ekman and Amna 2012, Teorell et al. 2007; Verba and Nie 1972). Typologies have become more sophisticated and focus around a number of dimensions, for example Verba and Nie (1972); voting, campaign activity, contacting and cooperative/communal activities dimensions; or Teorell et al. (2007); electoral participation, consumer participation, party activity, protest activity and contact activity. Ekman and Amna (2012) typology incorporates different forms of non-participation (or disengagement), involvement, including civic engagement (latent political) and political participation (manifest) which are then segmented into individual forms and collective forms.

We utilise questions from the MYPLACE survey on, voting in national elections, together with twenty additional questions covering different ways of being politically active during the previous twelve months. Factor analysis is used to reduce the number of items and to construct multi-item scales for our dependent variables. Leading from the item reduction we identified a typology of three distinct groups of political participation: Voting in National Elections, traditional forms of nonelectoral participation and protest action participation. The construction of these categories of participation are explored in more detail in the methodology section 12 Table 3 in the appendix.

Most research examines political engagement amongst young people at only a single country level, with little attention across different countries (Kitanova 2019; Norris 2003; Sloam 2016). Local political cultures and heritages can influence participatory behaviour, act as catalyst of as barriers. Recently, studies have examined issues across countries utilising the MYPLACE data (Grimm et al. 2017; Pollock et al. 2015). Additional studies have utilised data from waves 1-5 of the European Social Survey (ESS) (Sloam 2016) and Eurobarometer (20131) survey (Kitanova 2019) to examine youth political participation in the EU. These studies have identified that overall youth political participation varies across countries (Kitanova 2019; Sloam 2016). These are particularly nuanced, and shaped by local context, indigenous participatory cultures (Sloam 2016), with differences between the wealth of a state, and 'new' and 'old' democracies (Kitanova 2019; Sloam 2016).

Our data is of importance in being able to comparatively analyse, using an input harmonised instrument (Pollock 2018), a range of countries in terms of their diversity of democratic experiences. Our analysis shows distinct differences between locations in post-socialist countries which have shorter democratic trajectories than locations 
in other parts of Europe, though sometimes these differences are not so clear and suggest that within this group that there is also significant diversity. The importance of political path dependency across Europe has been noted elsewhere (Kitanova 2019). We incorporate Welfare State type (Kaariainen and Lehtonen 2006), including five categories; Post-socialist, Nordic, Conservative, Mediterranean and Liberal; the human development index (HDI) and the corruption perception index (CPI) as contextual variables. It is at this comparative level where our research makes the most substantial contribution to existing knowledge.

Therefore, we expect that:

H1: there are different levels of political participation, attitudes towards politics and political behaviour at both national and regional levels across Europe

\subsection{Demographics and participation}

The literature suggests that institutionalised political participation is unequal across specific demographic groups with age, gender, class and education all strongly correlating with political participation (Marien et al. 2010).

Age is a significant barrier to participation, with young people in most European countries not eligible to vote until they turn 18 years old. Politicians focus their attention predominantly on policy issues relevant to eligible voters. As a result, young people feel ignored and marginalised (Henn and Foard 2014), and are generally denied an effective voice and unable to play an active part in the political process (Furlong and Cartmel 2012, p. 26). This leads young people to participate in other forms of political expression including forms of protest politics (Stockemer 2014).

The literature frequently mentions gender as a significant barrier to participation

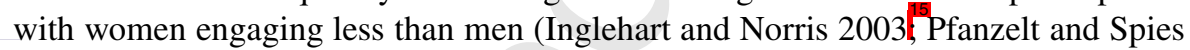
2018). It has been argued that gender socialisation from early life leads to lower levels of political motivation, interest, political knowledge and trust in political efficacy (Beauregard 2014l' Coffé and Bolzendahl 2010). However, some authors have pointed out that women are more likely to participate in cause orientated than campaign orientated activism (Childs 2004). This is evident in recent years, with women gaining more visibility with the Friday for the Future and \#MeToo movements.

The final focus is on social class. Socio-economic inequalities contribute to significant variations in political participation. Representative democracy has a middleand upper-class bias (Touchton and Wampler 2014, p. 1446). People with higher incomes, higher education and stable family situations, are typically more likely to participate in politics (Milbrath and Goel 1977, $\mathrm{Nie}$ and Verba 1987) and social and political organisations (Rosenstone and Hansen 20021). Parents with higher levels of education and a high socio-economic status pass onto their children through political socialisation, political awareness and social capital, including access to community and education resources, which leads to increased political participation (Flanagan and Levine 2010). Therefore, we hypothesise that:

$\mathrm{H} 2$ : participation is differentiated by demographics (age, gender and social class) 


\subsection{Democratic performance and participation}

Democratic performance is increasingly seen as a major factor in political participation. Democratic performance is defined and understood in different ways, however includes the following: "regime endurance or longevity; government efficacy; and, the fulfilment of liberal democratic values, or as a measure of the quality of democracy itself" (Foweraker and Landman 2002, p. 45). The democratic deficit (Norris 2011) is linked to falling trust in political institutions and the declining perception of political efficacy. Trust in government is a mainstay of democracy (Christensen and Laegreid 2003). Hooghe and Marien (2013) identify that citizens with high levels of political trust are more likely to participate in traditional or institutionalised forms of political participation. The reverse is true, with political trust negatively associated with participation in non-institutional forms. However, "it needs to be stressed that being distrustful and critical of representative democratic institutions is not necessarily the same as apathy and disinterest in politics; in fact, quite the contrary" (LSE 2013, p. 25). Negative press coverage of political integrity and performance has led to a negative orientation towards government and politicians, leading to cynicism and distrust (Dermody et al. 2010, Fu et al. 2011) therefore it is important to consider how young people are informed about politics and how media influences political efficacy and participation.

Verba et al. (1995) also state that both political interest and political efficacy are crucial determinants of political participation. Political efficacy or the perception of how citizens can effectively change politics through different means are explored by Niemi et al. (1991, p. 1407) who identify two components of political efficacy, including the self-perceived ability to understand politics and to participate in an effective manner. Henn and Foard (2014) distinguish between internal efficacy (own knowledge and understanding) and external efficacy (opportunities to participate meaningful in political affairs). These components also incorporate political competence and awareness (Hooghe and Marien 2013; Verba et al. 1995). The MYPLACE survey asked respondents three questions regarding political knowledge which were then aggregated into a political knowledge scale which can be considered as internal efficacy. This also links to interest in politics and how young people are kept informed about politics, as part of the political socialisation process (discussed below). External efficacy incorporates concerns regarding structural and institutional changes, which may lead to social dislocation, which makes young people less confident that political activity is likely to be effective (Horvath and Paolini 2014). These are considered as two types within the MYPLACE data, effectiveness of legal or non-violent activities and effectiveness of illegal or violent activities.

We also asked young people two questions around democracy; First, how young people feel about democracy as a political system. This is important due to Eastern European countries adopting democracies over communist regimes since 1989. Secondly, the performance of a democracy through issues of trust, cynicism, efficacy and perception of politicians being interested in young people all contribute to an overall satisfaction with democracy. We therefore hypothesis that:

H3: poor perceptions of democratic performance decrease participation 


\subsection{Political socialisation and participation}

Sigel (1965) states that political socialisation is "the process by which persons learn to adopt the norms, values, attitudes, and behaviours accepted and practiced by the ongoing (political) system". Political socialisation of young people starts at home. In order to participate in politics, young people need information on which to base their participatory decisions and acts (Verba et al. 1995). This information through political discussion and political interest are the most important determinates of political participation (Marien et al. 2010). Research into political socialisation shows that children growing up in families who discuss politics, are more likely to acquire awareness, knowledge and understanding about politics, and a greater degree of political confidence (Henn and Foard 2014), increasing participation.

However, recent research has moved focus from parents and schools, and includes voluntary associations, mass media, peer groups and informal interactions (Hooghe 2004). Young people keep themselves informed about politics and current affairs through different forms of media consumption as well as discussion with peers. 'Informational use of media stimulates youth discussion and expression, which in turn boosts civic and political participation' (Lee et al. 2012/ 2 p. 686). Following from the above, we consider political socialisation at a number of levels: individual, family and institution levels.

At an individual level, the MYPLACE survey asked young people questions about political interest, political knowledge for example in Henn and Foard's (2014) internal efficacy, and how much time the young person spends keeping themself informed about politics/current affairs.

At a family level, we included learnt behaviours, including how often parents vote in elections, the perceived Interest in politics of parents, and how often the young person discusses political issues with their parents.

It is also important to consider the institutional level in the political socialisation (Hooghe 2004). Aside from school, religious institutions are among the few places where young people interact with adults outside their families (Pearson-Merkowitz and Gimpel 2009). Religious leaders, as spiritual and moral leaders, make political speeches raising awareness of issues and encouraging members to participate and act upon these (Djupe and Gilbert 2002; Pearson-Merkowitz and Gimpel 2009). However, affiliation and attendance at religious institutions varies markedly across age groups and our study locations. Pew Research Center's (2018) study of religious commitment identified that weekly attendance at religious institutions varied from $25 \%$ of the population in Portugal to only two percent in Estonia. Young people and adults also interact in other settings including clubs, groups and civic organisations. We also capture membership, participation and/or volunteering at fifteen different types of organisations, as a participation index. Therefore, In this paper, we incorporate attendance at religious events and participation across a range of organisations, as forms of organisational political socialisation. Young people who have access to a range of organisations develop social capital, leading to an increase in political participation (Flanagan and Levine 2010). Therefore, we propose the following hypothesis; 
H4: political socialisation (through political interest and knowledge, parents voting and discussing politics and organisational contacts) increases the levels of participation

Finally, we aim to understand differences in political participation of young people across Europe. One of the main goals of this research was to explore how local context influences participatory behaviour. Therefore, we expect;

H5: that the local context (i.e. demographics, democratic performance and political socialisation) are significant between different forms of participation.

\section{Data and methodology}

\subsection{MYPLACE data}

The MYPLACE questionnaire survey was a common research instrument administered to a representative sample of 16-25 year olds in 30 carefully selected research locations (illustrated in Fig. 1) in 14 different countries. The data was collected between September 2012 and April 2013, with an achieved overall sample of 16,935. Each participating country selected two contrasting locations (with 4 in Germany: 2 in the old East and 2 in the old West) where the criteria for selection was that there were a priori reasons to suggest that the attitudes, behaviour and experiences of the young people would be different. This means that we have a range of re-

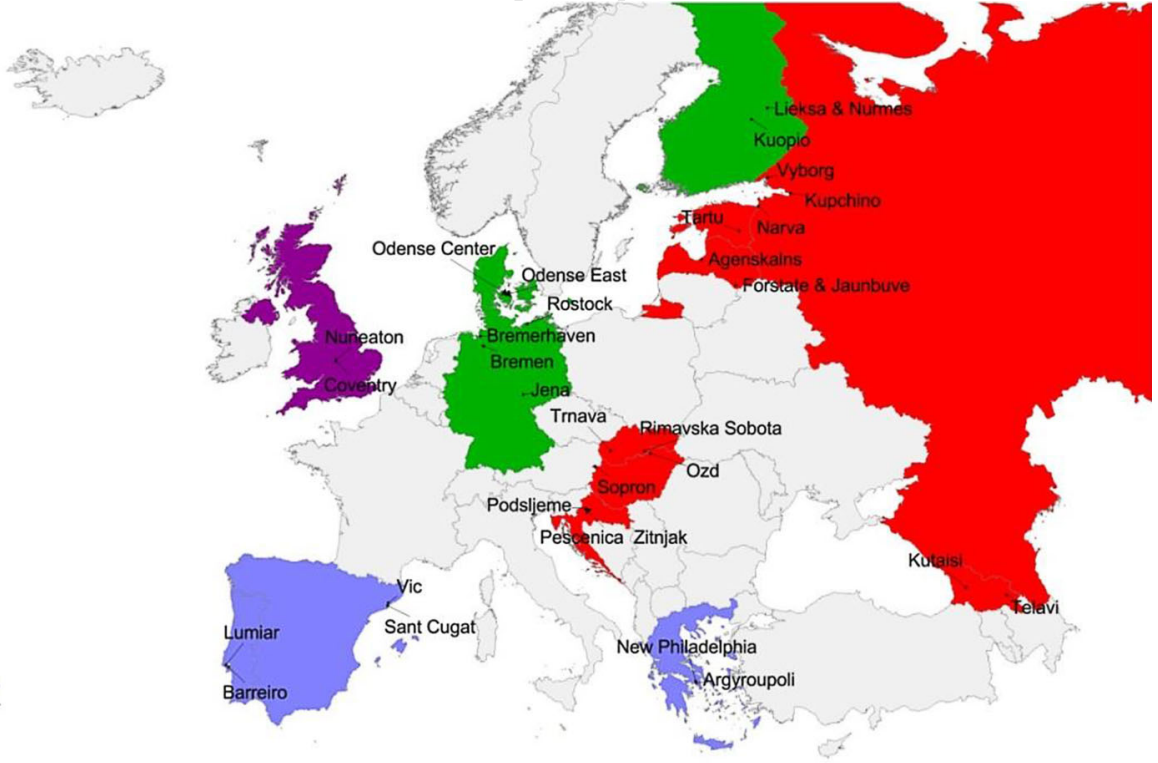

Fig. 1 Research locations included in the MYPLACE project 
search sites, each with distinct features which are unique to themselves and which require an understanding of local as well as national contexts to fully appreciate the reasons why young people hold the attitudes that they do. It is important to reiterate that these are a series of local case studies and not nationally representative results (Pollock 2018). This data set captured an important moment in Europe at the start of the wave of post austerity populism that has swept through the continent. The seeds of the contemporary hold that populist and Eurosceptic forms of politics have taken are present in this data and formed important analytic themes (Grimm et al. 2017; Pollock et al. 2015).

Participating countries reflect European diversity in terms of level of integration (for instance EMU and Schengen membership), length of membership (founding members like Germany, second Spain and Portugal and third wave Estonia, Slovakia) prospective members (in case of Croatia), welfare regimes and historic legacies (post socialist, southern European dictatorships, long established stable democracies). We can also differentiate between degrees of impact of the recent economic crisis and the sovereign debt crisis with stable economies in the north and economies struggling with austerity measures in the south.

\subsection{Approach to data analysis}

The analysis of the MYPLACE data are presented in two sections. The first section provides a descriptive analysis at either a consortium wide level or a location level (based on the 30 individual locations) for key dependent variables including: 'voting in national elections', 'traditional participation', 'protest action participation'. To analyse the political behaviour of young people beyond electoral participation, the MYPLACE survey included questions on 20 different political activities (see Table 3 in the appendix). Respondents were asked if they had undertaken each of these activities once, twice or three or more times in the last 12 months. Factor analysis was used to identify specific components within the 20 activities and for the purposes of this paper two groups are used; traditional forms of participation (five activities) and protest action (five activities). These groups were tested for internal reliability using Cronbach's alpha at a consortium and national level to ensure a consistent measure of the concept. To standardise each derived variable, a participation score out of 100 was created for each. We then present key independent variables addressing barriers to participation of; 'efficacy', 'trust towards core national political institutions', 'cynicism: attitudes towards politicians and politics', 'satisfaction with democracy', 'positive views towards a democratic system'. Independent variables were constructed using the same method as the dependent variables, drawing on a range of questions and tested for internal reliability.

Secondly, we present three multi-level regression models, to identify significant coefficients of participation and to compare and contrast the different forms of participation. Multi-level regression models are appropriate when data are nested, like the MYPLACE data i.e. individuals within a study location, nested within a country. The literature suggests that a number of variables should be predictors of participation. As discussed, these can be grouped under demographics, democratic performance, political socialisation, and contextual. We have included demographic variables such 
as age and gender, together with parental social class (parental employment and education when respondent was aged 14). Democratic performance includes the levels of trust in political institutions, cynicism towards politicians, interest that politicians have in young people, together with satisfaction with democracy, positive views towards a democratic system and efficacyl'(both non-violent/legal and violent/illegal efficacy. Political socialisation includes Individual influences includes; the young person's political interest, political knowledge (Internal efficacy) and how much time they spend keeping yourself informed about politics/current affairs. Family influences includes; Interest in politics of parents, how often they discuss political issues with parents and how often do parents vote in elections. Organisational influences included attendance at religious events, membership of political parties and a civic participation index. In addition to the individual variables additional contextual variables we have used are Welfare State type (Kaariainen and Lehtonen 2006), including five categories; Post-socialist, Nordic, Conservative, Mediterranean and Liberal; the human development index (HDI) and the corruption perception index (CPI).

Table 4 in the appendix illustrates the logic of the thematic clustering for the independent variables used in the regression modelling. Three models were tested: Model A: Traditional participation, Model B: Protest Action and Model C: Voting (only eligible participants) — have voted/have not voted for a variety of reasons. The dependent variables for traditional participation and protest action participation are scale variables (measured on a $0-100$ scale with $0=$ no participation, maximum participation); therefore a standard multi-level model is used. Voting is a binary variable $(1=$ voted, $0=$ did not vote $)$, therefore a logistic multi-level model is used.

\section{Results}

\subsection{Describing youth political engagement across Europe}

The descriptive analysis that follows presents, for each location in the study, the mean values on a series of scales and variables which help us to understand the aggregate picture across Europe, and address H1: that there are different levels of political participation, attitudes towards politics and political behaviour at national and regional levels across Europe. These charts are colour coded (red, green, purple and blue) to match the country groupings illustrated in Fig. 1. Figs. 2, 3 and 4 present our dependant variables, Figs. 5, 6 and 7 illustrate democratic performance, and Figs. 8 and 9 forms of political socialisation.

Firstly, looking at the whole sample of young people in all our research locations who were eligible to vote, $70.3 \%$ voted in the last national election. This is considerably higher than results in the Eurobarometer and ESS studies and reinforces the need to understand that our survey data is not nationally representative but is representative of the chosen locations. Of the eligible young people who didn't vote, $11.7 \%$ were 'unable to on the day', $8.0 \%$ stated that 'for me, voting or not is equally pointless', $5.9 \%$ stated that 'no party aligned to views' and $4.1 \%$ 'did not vote to show my dissatisfaction with politicians and parties'. 
Fig. 2 Overall Voting in National Elections $(\%)$ by location

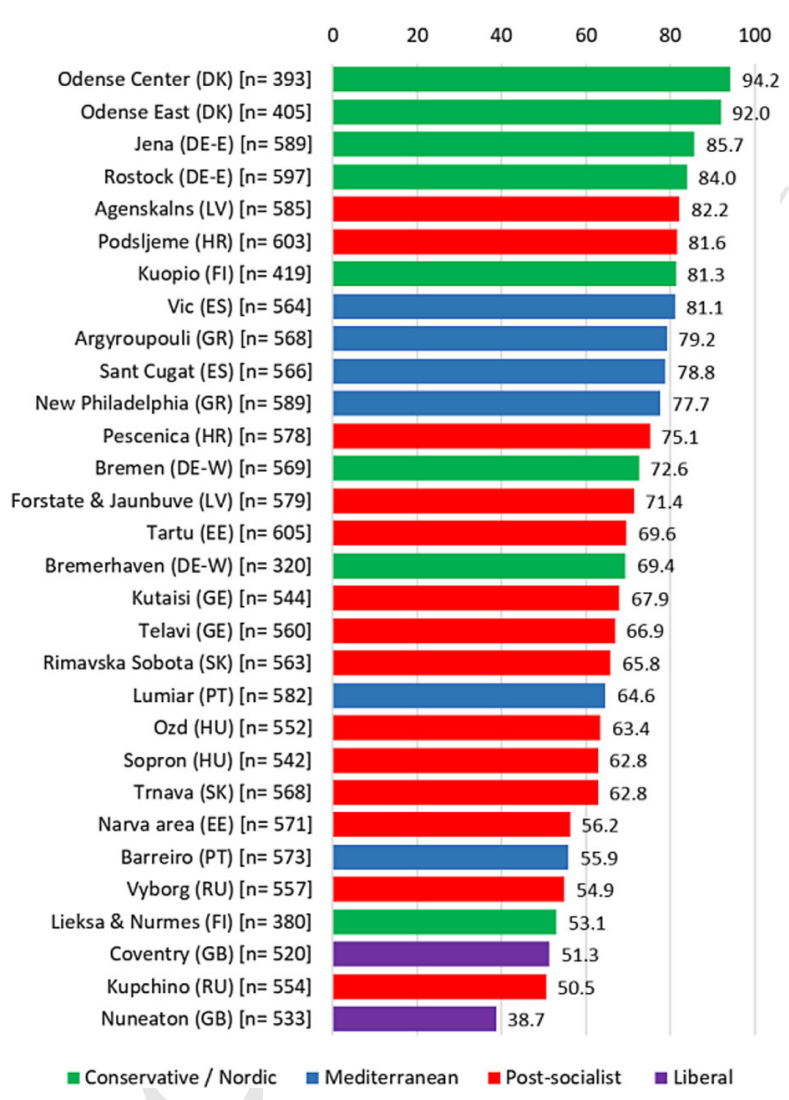

Fig. 2 illustrates the percentage of young people voting in national elections broken down by research location. The locations vary to a large degree from Odense Center (DK), with $94.2 \%$, and Nuneaton (UK), 38.7\% with the lowest rates of voting. Of interest is the relative closeness most pairs of national locations, with the exception of Finland, which suggests that for many countries there may be evidence of a national propensity.

Fig. 3 illustrates the participation scale for young people taking part in traditional forms of participation ( 5 activities) 12 months prior to the survey. The survey asked if respondents had; 'Volunteered in an election campaign', 'Contacted a politician or local councillor', 'Collected signatures', 'Given a political speech', or 'Distributed leaflets with a political content'. These questions have been used to create a participation scale on a 0 to 100 scale, with 100 representing most active. The overall average for all locations is 3.31 demonstrating low levels of participation. This varies from Jena (DE-E), with 5.3, with the highest score of traditional participation to Sopron (HU), 0.4 with the lowest rates.

Fig. 4 illustrates the participation scale for young people taking part in forms of protest action participation (5 activities) 12 months prior to the survey. The survey asked a series of Protest Action questions; including; 'Participated in a demonstra- 
Fig. 3 Traditional forms of Participation by location

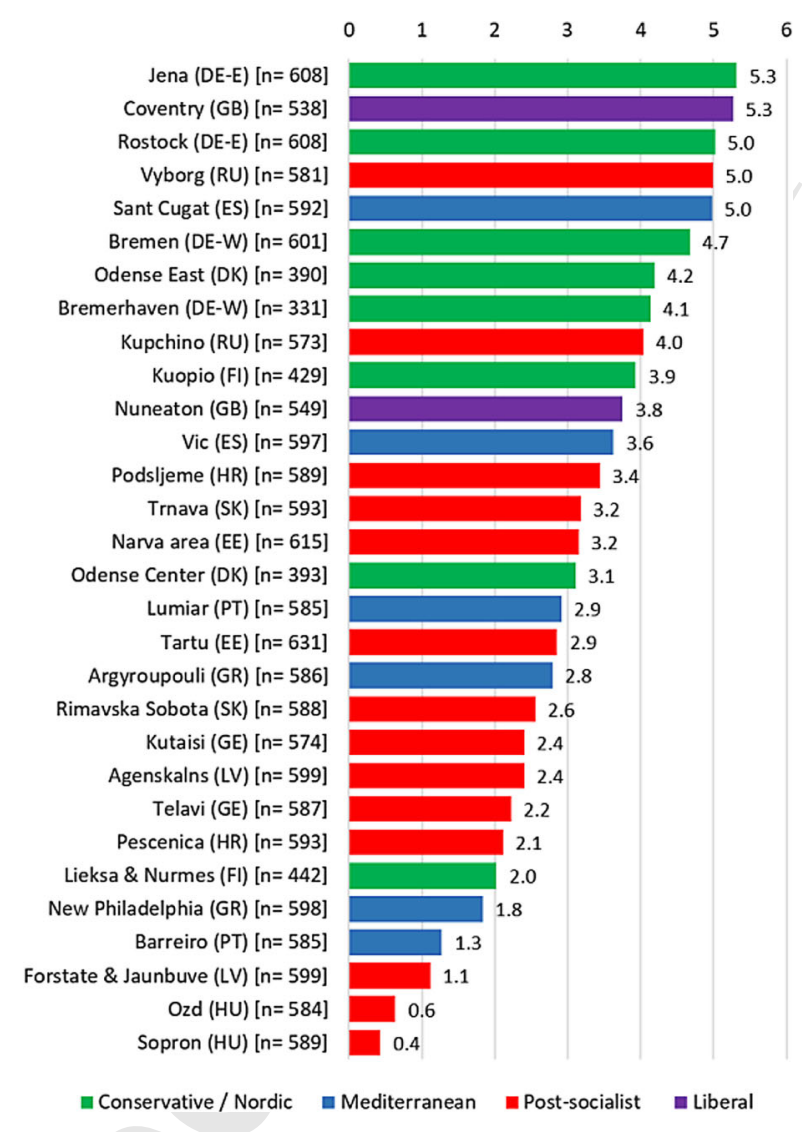

tion', 'Participated in a strike', 'Participated in a violent political event', 'Occupied buildings or blocked streets/railways' and 'Participated in a 'flashmob'. These questions have been used to create a protest action scale on a 0 to 100 scale, with 100 representing most active. The overall average for all locations is 5.4 demonstrating low levels of protest action participation. There is a large variation between locations, varying from Sant Cugat (ES) 20.10 with the highest scale of protest action participation to Ozd (HU), 1.0 with the lowest rates. Locations in Spain, Greece, and Germany have the highest proportions of young people participating in protest actions. We need to remember that during this time there were a great many demonstrations in Greece and Spain protesting about austerity and the strategy of the EU in regard to countries with acute financial problems.

Fig. 5 illustrates young people's trust in political institutions. The survey asked questions regarding levels of trust towards 'core national political institutions', 'the head of government/PM', 'parliament' and 'political parties'. These were combined to create a 'Trust' variable and standardised on a 0 to 100 scale, with 100 representing the greatest trust. The overall average for all locations is 41.8 demonstrating relatively low levels of trust towards political institutions. This varies from Kuopio 
Fig. 4 Protest Action by location

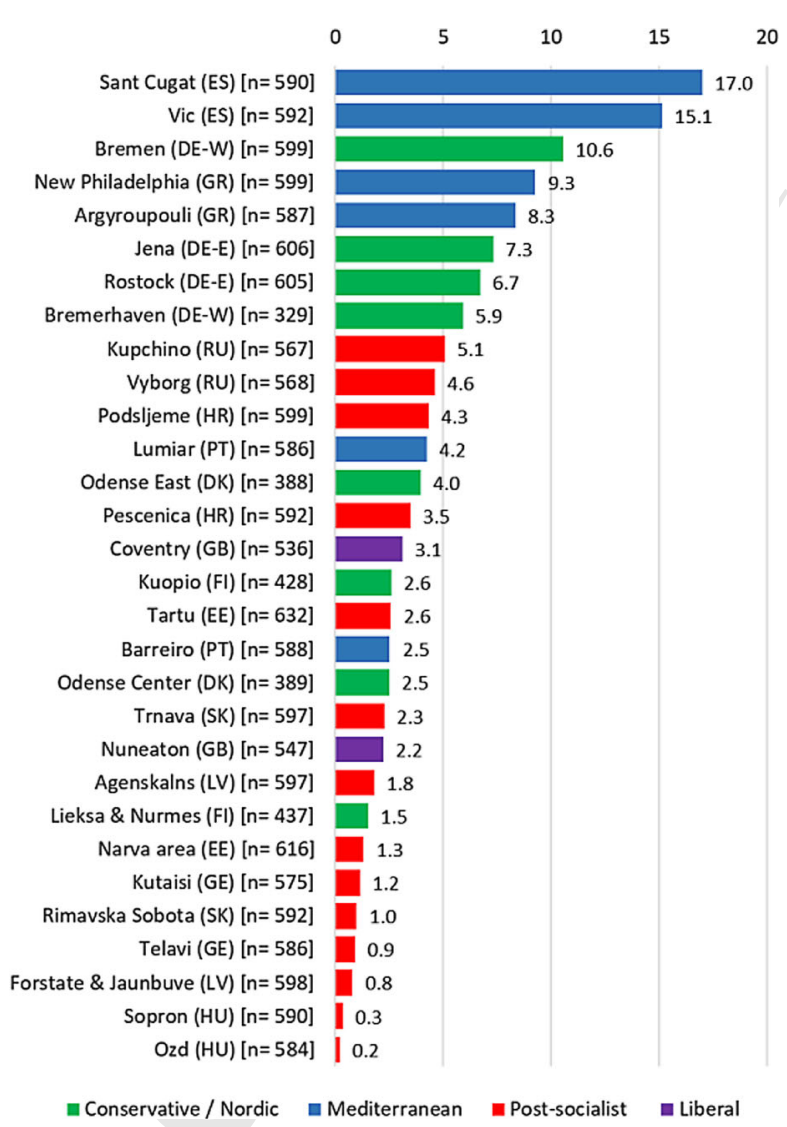

(FIN) with 61.8 with the highest levels of trust to Argyroupouli (GRE) with 24.2 with the lowest levels of trust.

Fig. 6 illustrates young people levels of cynicism towards politicians and politics. The survey asked two questions; 'Politicians are corrupt' and 'The rich have too much influence over politics' which have been combined to create a 'Cynicism' variable standardised on a 0 to 100 scale, with 100 representing most cynical. The overall average for all locations is 69.2 demonstrating high levels of cynicism towards politicians and politics. This varies from New Philadelphia (GRE) with 85.7 with the highest levels of cynicism to Odense Center (DEN), 43.2 with the lowest levels of cynicism. Locations in Mediterranean countries of Greece, Portugal and Spain are most cynical of politicians and politics.

Both Figs. 5 and 6 suggest a certain Nordic propensity for high trust/low cynicism and the opposite for the Mediterranean locations. It is of interest that the postsocialist locations sat between these two poles.

The survey asked the question 'On the whole, how satisfied are you with the way democracy works in [country]?' This was standardised on a 0 to 100 scale, with 100 representing most satisfied. The overall average for all locations is 50.1 demonstrating average levels of satisfaction with democracy. This varied from Odense Center 
Fig. 5 Trust in political institutions by location

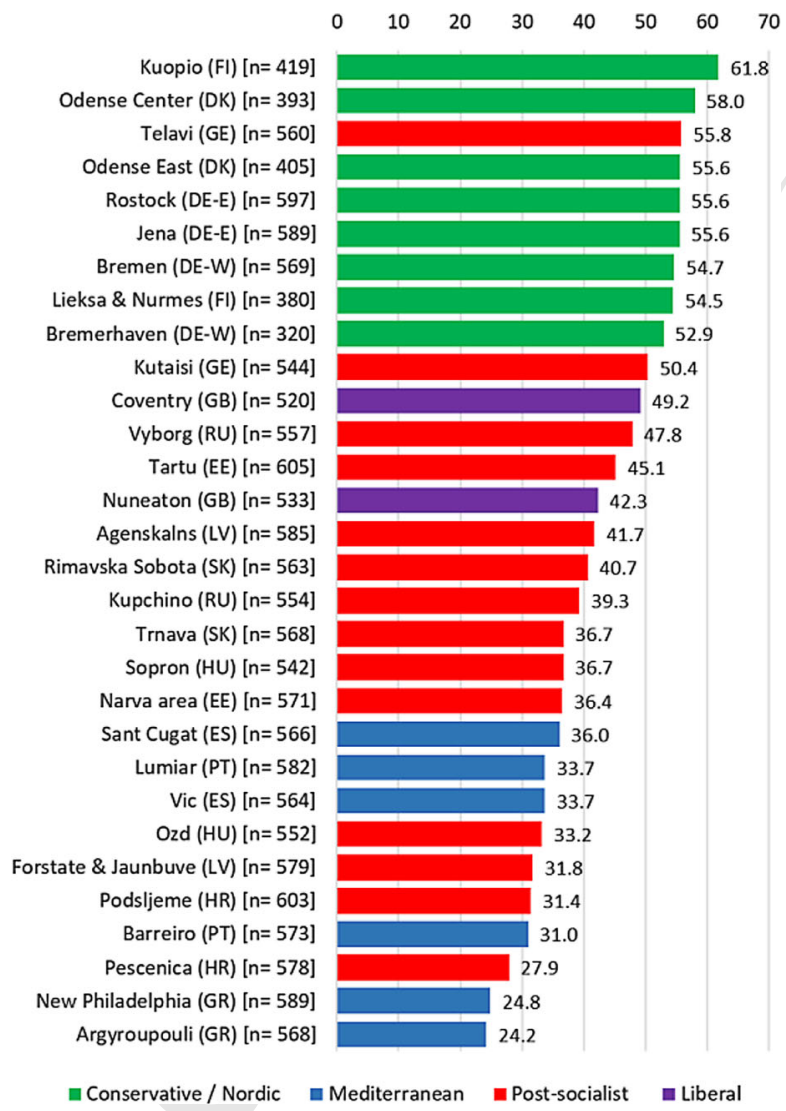

(DEN) with 74.3, with the highest satisfaction with democracy to New Philadelphia (GRE), 33.4 with the lowest satisfaction with democracy. There is strong regional variations with locations in Denmark, Finland and Germany with the highest levels of satisfaction followed by post-socialist countries and Mediterranean countries the lowest levels of satisfaction.

Respondents were also asked about their support for democratic systems 'Having a democratic, multi-party system' and 'Having an opposition that can freely express its views'. These were combined and standardised on a 0 to 100 scale, with 100 representing high levels of support towards democratic systems. The overall average for all locations is 72.7 , demonstrating very high levels of support for Democratic systems. This varies from Odense Center (DEN), 86.3, with the highest levels of support to Vyborg (RUS), 59.3 with the lowest levels of support.

Fig. 7 illustrates very clear regional groupings when comparing mean location values of satisfaction with democracy (x-axis with low satisfaction on the left to high satisfaction of the right) by views on democratic systems (y-axis with negative views at the bottom to positive views at the top). Locations in the Mediterranean countries (blue) cluster and have positive views on democratic systems, but have level low levels of satisfaction with democracy. The Danish, German and Finnish 
Fig. 6 Cynicism by location

$\begin{array}{llllllllll}0 & 10 & 20 & 30 & 40 & 50 & 60 & 70 & 80 & 90\end{array}$

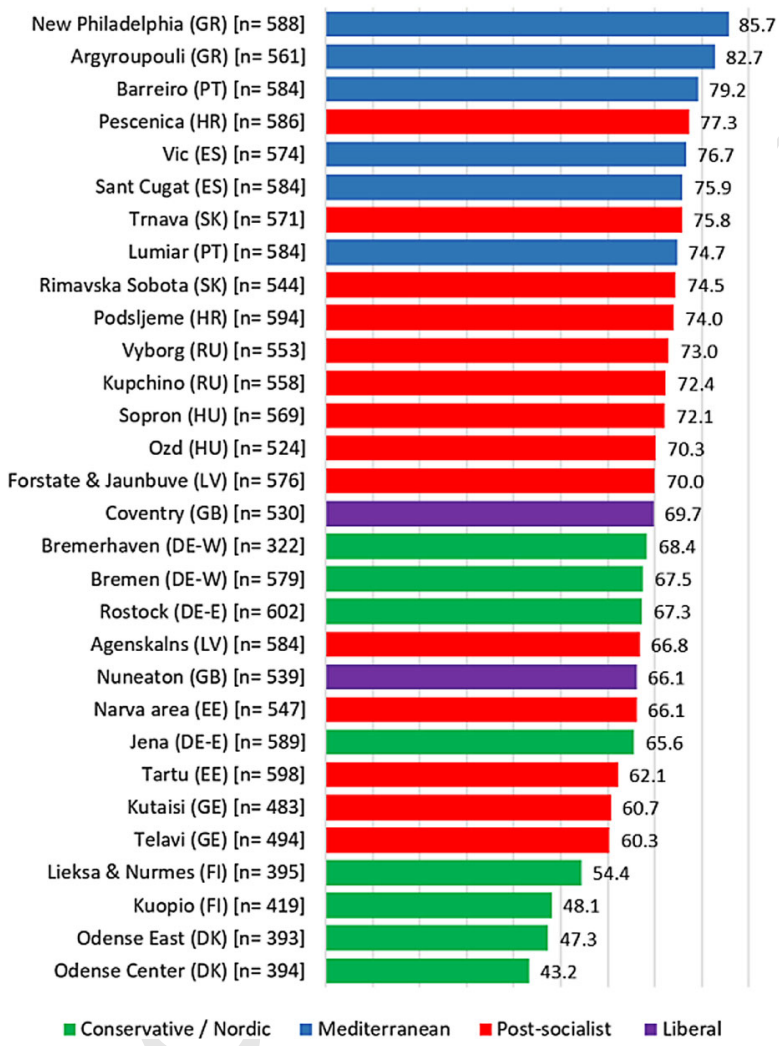

(green) locations are generally clustered in the top right with positive views towards democratic systems and high levels of satisfaction with democracy. Locations in post-socialist countries (red) are clustered occupying the centre of the graph. Of the two UK locations, Coventry is closest to the Danish and Germans and Nuneaton with the post-socialist locations cluster.

Young people's interest in politics is captured in Fig. 8, standardised on a 0 to 100 scale, with 100 representing the most interested. The overall average for all locations is 44.6, demonstrating medium levels of interest in politics. This varies from Jena (DE-E) with 61.7 with the highest levels of interest to Sopron (HU), 30.0 with the lowest levels of interest. Young people in locations in Germany and Denmark are clearly have the most interest in politics, and locations in Hungary are least interested, though low levels are also observed in locations in Latvia, Slovakia and Portugal.

Taking political interest a little further, Fig. 9 illustrates the frequency of young people discussing political issues with parents, standardised on a 0 to 100 scale, with 100 representing the highest frequency. The overall average for all locations is 33.3 demonstrating low frequencies of discussion. This varies from Sant Cugat (ES) with 46.8 , with the highest frequency of discussion, to Sopron (HU), 23.7 with the lowest 


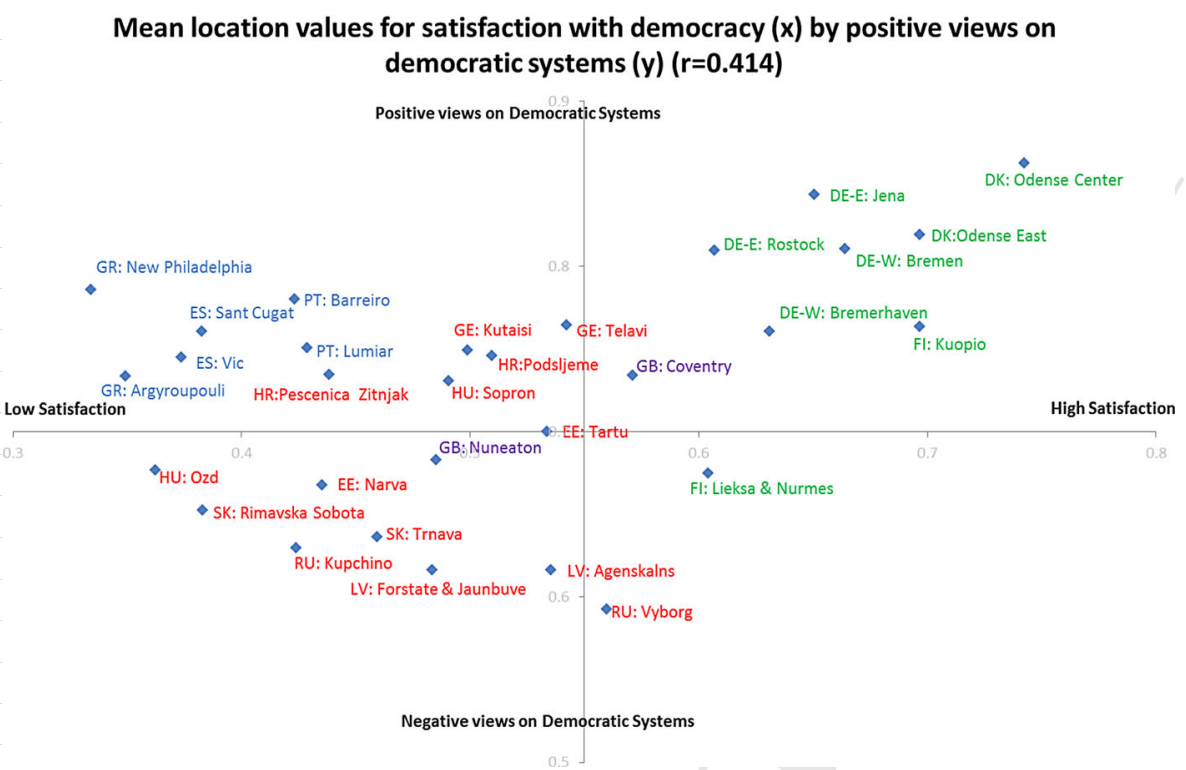

Fig. 7 Satisfaction with democracylby positive views on democratic systems $(n=10,899)$

frequency of discussion. Moreover, there is strong regional variations with locations in Spain and Denmark with the highest frequency of discussion about politics. Postsocialist countries have the lowest frequency of discussion about politics. There is, as would be expected a certain correspondence between the responses to this question and general political interest.

\subsection{Enablers and barriers to political participation}

The multilevel regression analysis that follows, presents variables the literature states should be predictors of participation at an individual level, together with broader country level contextual variables. Results from the multiple regression analysis addresses hypotheses $2-5$. Table 1 illustrate the results if the three regression models (empty model, individual level and country level variables) for each of the three dependent variables.

The importance of locally specific explanations (hence multi-level modelling) is illustrated by the intra class correlations. For two of the three models demonstrates that it would be inappropriate to treat the data set as unstructured. The analysis must take into account that there are 30 different locations as by doing so the predictive power of the models is significantly enhanced by $16.4 \%$ for protest action and $7.7 \%$ for voting, however, public traditional is only $1.8 \%$.

Table 2 presents the coefficients (B), levels of significance and standard error (SE) for individual and contextual variables for the three models. Firstly, addressing the contextual variables; the country level variable indicating welfare state type (Esping-Andersen 1990, Kääriäinen and Lehtonen 2006) identified a significant contrast between post-socialist countries and Mediterranean countries, which are 
Fig. 8 Young person's interest in Politics by location

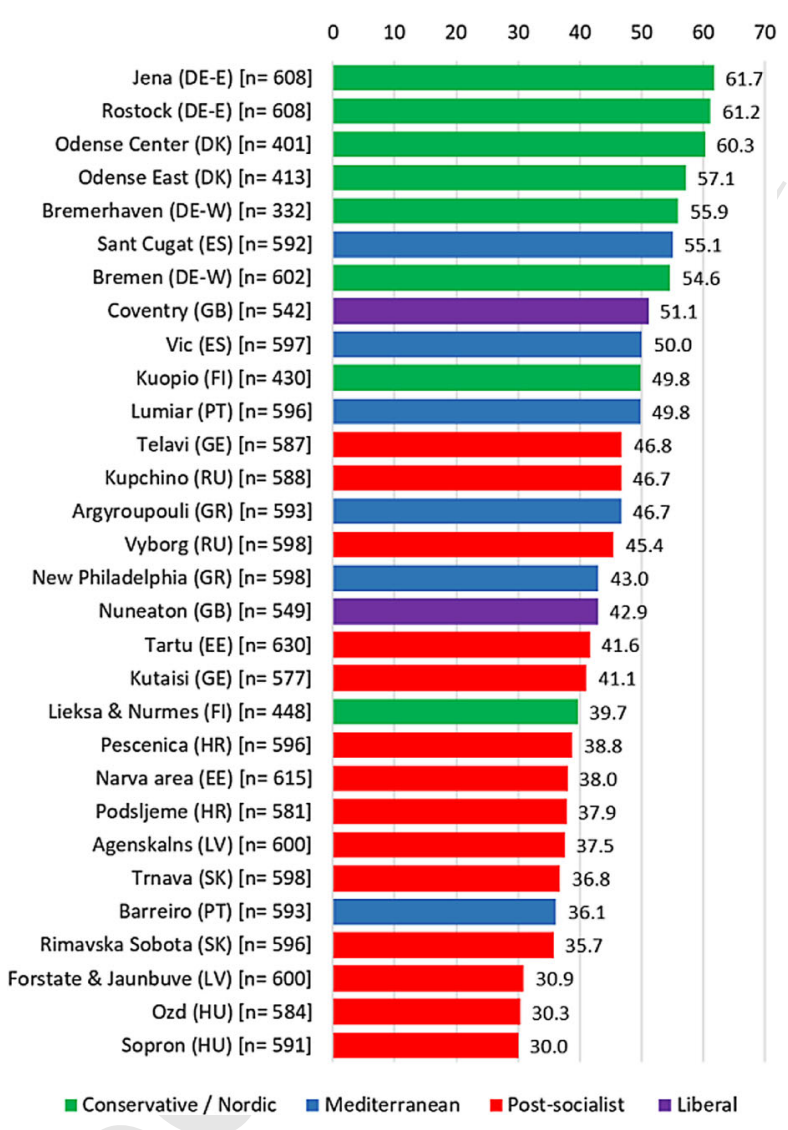

more likely to participate in protest action; and Liberal (UK) locations which are less likely to vote. The higher a country is on the Human Development Index, the more likely young people are to vote $(p<0.01)$ and participate in protest action $(p<0.1)$. These findings further support $\mathrm{H} 1$, however, the corruptions perception index is not a significant contextual variable. Table 2 presents coefficients under the following groups, by our three types of participation. This allows a comparison between the types to test H5. These are discussed individually and across models below.

\subsection{Demographics barriers}

With regards to demographic barriers (H2), contrary to the literature (Marien et al. 2010), there were no statistical significant differences between males and females for traditional forms of participation and voting in national elections. However, males were more likely (at $p<0.1$ ) than females to participate in protest action. This is likely due to the gender socialisation. The youngest in the survey are more likely to participate in traditional participation and protest action than older youth because these are the only means to participate politically at such a young age. Of the 
Fig. 9 Talk to parent's about politics by location

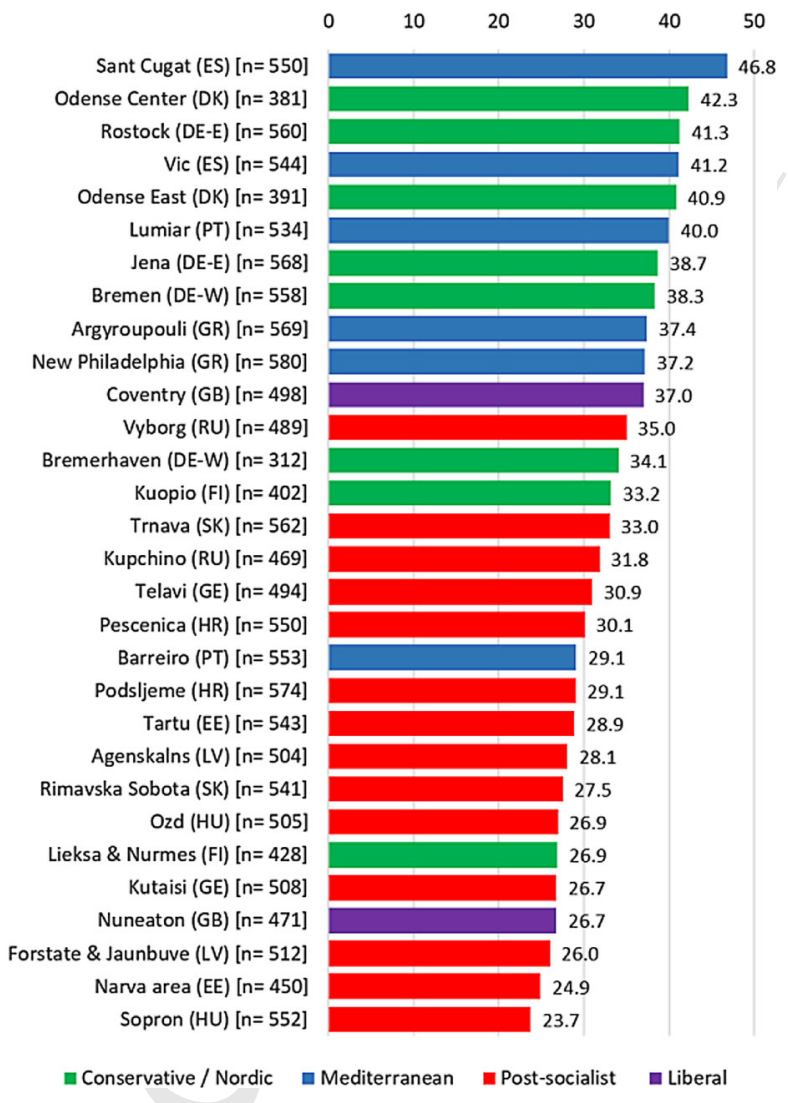

young people who were eligible to vote, the older amongst them were most likely to vote $(p<0.1)$. Social class shows to be significantly associated with participation. Respondents with a lower parental class are less likely to participate in traditional forms and protest action than respondents with a high parental social class. This is also true for voting in national elections, although at $p<0.1$.

\subsection{Democratic performance barriers}

Addressing H3, young people with lower levels of trust in political institutions and higher levels of cynicism are more likely to participate in protest action. However, young people who are less cynical about politicians are more likely to vote. Young people with lower levels of satisfaction with democracy are more likely to participate in traditional forms and protest action. Efficacy shows to be significantly associated with participation, in accordance with Norris (2011). Legal forms of efficacy have positive significant relationships with voting, traditional and protest action forms of participation. As expected, respondents who feel that illegal forms of efficacy (illegal and violent protest activities) can influence politics in their country have a significant positive association with protest action and a significant negative 
Table 1 Variance components of/regression models

\begin{tabular}{lllll}
\hline & & $\begin{array}{l}\text { Empty model } \\
\text { (random intercept } \\
\text { only)-Model 0 }\end{array}$ & $\begin{array}{l}\text { With individual } \\
\text { level explanatory } \\
\text { var's-Model 1 }\end{array}$ & $\begin{array}{l}\text { With country } \\
\text { level explanatory } \\
\text { var's_Model 2 }\end{array}$ \\
\hline $\begin{array}{l}\text { Model A: } \\
\text { Public }\end{array}$ & $\sigma$ (individual level) & 0.009690 & 0.007437 & 0.007437 \\
Tradi- & $\sigma$ (location level) & 0.000176 & 0.000057 & 0.000051 \\
tional & -2 log likelihood & $-19,575.6$ & $-22,252.8$ & $-22,207.6$ \\
& df & 3 & 27 & 33 \\
Model B: & $\sigma$ (individual level) & 0.009871 & 0.008475 & 0.008475 \\
Protest & $\sigma$ (location level) & 0.001933 & 0.001337 & 0.000692 \\
Action & -2 log likelihood & $-19,275.3$ & $-20,718.9$ & $-20,703.0$ \\
& df & 3 & 27 & 33 \\
Model $C:$ & $\sigma$ (individual level) & 0.522718 & 0.2308272 & 0.224420 \\
Voting & $\sigma$ (location level) & 0.147076 & 0.091384 & 0.077485 \\
& -2 log likelihood & $32,376.709$ & $34,164.147$ & $34,208.155$ \\
& df & 3 & 27 & 33 \\
\hline
\end{tabular}

$(p<0.05)$ association with voting in national elections. Respondents with positive views to democracy as a political system are more likely to vote. Respondents with lower levels of satisfaction with democracy are more likely to participate in both traditional and protest action.

\subsection{Political socialisation}

Hypothesis (H4) addresses political socialisation though individual political interest and knowledge, parenteral influence and organisational contacts is examined at multiple levels. As literature has stated (Marien et al. 2010), young people who are interested in politics are significantly $(p<0.001)$ more likely to participate in the three forms of participation. Respondents with the highest knowledge of politics are more likely to vote in national elections than respondents with less knowledge. However, respondents with limited political knowledge are more likely to participate in protest action than respondents with the highest political knowledge. Although significant, young people keeping themselves informed about political issues has a negligible effect. Political socialisation via parents is significant, which is consistent with previous studies (Henn and Foard 2014). The more the young people discuss politics with their parents, the more likely they are to participate in traditional voting forms of participation and protest action. Parents participating in elections also has a strong association with young people voting $(p<0.001)$ and participating $(p<0.1)$. However, parents' interest in politics has a negative association with both traditional forms of participation and voting.

As we had expected, at an organisational level, young people who are members of political parties are more likely to participate and vote than non-members. This is also the case for young people who participate in a range of civic engagements. Similarly, young people who are attend religious events on a frequent basis are more likely to vote than people who don't. It is of interest, however, that young people 
Table 2 Multilevel regression models 30 for traditional participation (A), protest action (B) and voting (C) Model A: Traditional Model B: Protest Action $\quad$ Model C: Voting n2=33 $\mathrm{n} 2=33 \mathrm{n} 1=10,902 \quad \mathrm{n} 2=33 \mathrm{n} 1=10,899 \quad \mathrm{n} 1=7008$

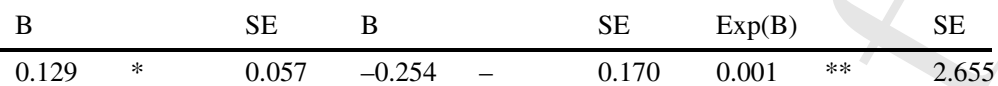

Intercept

Individual variables

Demographics

\begin{tabular}{|c|c|c|c|c|c|c|c|c|c|}
\hline Male & 0.002 & - & 0.002 & 0.003 & $\sim$ & 0.002 & 1.056 & - & 0.088 \\
\hline Female (ref) & - & - & - & - & - & - & - & - & - \\
\hline Age & -0.001 & $*$ & 0.000 & -0.001 & $*$ & 0.000 & 1.034 & $\sim$ & 0.019 \\
\hline $\begin{array}{l}\text { Parental So- } \\
\text { cial Class 1: } \\
\text { (low) }\end{array}$ & -0.005 & $*$ & 0.002 & -0.008 & $* * *$ & 0.002 & 0.821 & $\sim$ & 0.104 \\
\hline $\begin{array}{l}\text { Parental So- } \\
\text { cial Class } 2\end{array}$ & -0.004 & - & 0.003 & -0.007 & $*$ & 0.003 & 1.115 & - & 0.110 \\
\hline $\begin{array}{l}\text { Parental So- } \\
\text { cial Class } 3\end{array}$ & -0.001 & - & 0.003 & -0.002 & - & 0.003 & 1.074 & - & 0.099 \\
\hline $\begin{array}{l}\text { Parental So- } \\
\text { cial Class 4: } \\
\text { High (ref) }\end{array}$ & - & - & - & - & & - & - & - & - \\
\hline \multicolumn{10}{|c|}{ Democratic performance } \\
\hline $\begin{array}{l}\text { Trust in } \\
\text { Political } \\
\text { Institutions }\end{array}$ & -0.001 & - & 0.005 & -0.022 & $* * *$ & 0.006 & 0.980 & - & 0.256 \\
\hline Cynicism & 0.009 & $*$ & 0.005 & 0.018 & $* * *$ & 0.005 & 0.712 & $*$ & 0.147 \\
\hline $\begin{array}{l}\text { Politicians } \\
\text { interest } \\
\text { in Young } \\
\text { People }\end{array}$ & -0.014 & $* * *$ & 0.004 & 0.004 & - & 0.004 & 0.771 & - & 0.196 \\
\hline $\begin{array}{l}\text { Satisfaction } \\
\text { with Democ- } \\
\text { racy }\end{array}$ & -0.016 & $* *$ & 0.004 & -0.043 & $* * *$ & 0.005 & 0.939 & - & 0.252 \\
\hline $\begin{array}{l}\text { Positive } \\
\text { view to- } \\
\text { wards } \\
\text { Democracy }\end{array}$ & -0.013 & $* *$ & 0.005 & -0.009 & - & 0.005 & 1.679 & $*$ & 0.247 \\
\hline $\begin{array}{l}\text { Legal Effi- } \\
\text { cacy }\end{array}$ & 0.029 & $* * *$ & 0.006 & 0.028 & $* * *$ & 0.006 & 2.156 & $*$ & 0.273 \\
\hline $\begin{array}{l}\text { Illegal Effi- } \\
\text { cacy }\end{array}$ & -0.003 & & 0.004 & 0.042 & $* * *$ & 0.004 & 0.662 & $* * *$ & 0.122 \\
\hline \multicolumn{10}{|c|}{ Political Socialisation } \\
\hline $\begin{array}{l}\text { Interest in } \\
\text { Politics }\end{array}$ & 0.043 & $* * *$ & 0.004 & 0.030 & $* * *$ & 0.004 & 3.011 & $* * *$ & 0.129 \\
\hline $\begin{array}{l}\text { Political } \\
\text { Knowl- } \\
\text { edge 1: Low }\end{array}$ & 0.005 & $\sim$ & 0.003 & 0.010 & $* *$ & 0.004 & 0.371 & $* * *$ & 0.156 \\
\hline $\begin{array}{l}\text { Political } \\
\text { Knowl- } \\
\text { edge } 2\end{array}$ & -0.001 & - & 0.003 & -0.002 & $*$ & 0.003 & 0.439 & $* * *$ & 0.119 \\
\hline
\end{tabular}


Table 2 (Continued)

\begin{tabular}{|c|c|c|c|c|c|c|c|c|c|}
\hline & \multicolumn{3}{|c|}{$\begin{array}{l}\text { Model A: Traditional } \\
\mathrm{n} 2=33 \mathrm{n} 1=10,902\end{array}$} & \multicolumn{3}{|c|}{$\begin{array}{l}\text { Model B: Protest Action } \\
\mathrm{n} 2=33 \mathrm{n} 1=10,899\end{array}$} & \multicolumn{3}{|c|}{$\begin{array}{l}\text { Model C: Voting } \mathrm{n} 2=33 \\
\mathrm{n} 1=7008\end{array}$} \\
\hline & $\mathrm{B}$ & & SE & $\mathrm{B}$ & & SE & $\operatorname{Exp}(B)$ & & SE \\
\hline $\begin{array}{l}\text { Political } \\
\text { Knowl- } \\
\text { edge } 3\end{array}$ & -0.001 & - & 0.002 & 0.001 & $\sim$ & 0.002 & 0.750 & $* *$ & 0.105 \\
\hline $\begin{array}{l}\text { Political } \\
\text { Knowl- } \\
\text { edge 4: High } \\
\text { (ref) }\end{array}$ & - & - & - & - & - & - & - & - & - \\
\hline $\begin{array}{l}\text { Inform on } \\
\text { politics }\end{array}$ & 0.000 & $* * *$ & 0.000 & 0.000 & $* * *$ & 0.000 & 1.001 & 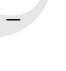 & 0.001 \\
\hline $\begin{array}{l}\text { Parent's } \\
\text { interest in } \\
\text { politics }\end{array}$ & -0.024 & $* * *$ & 0.004 & -0.005 & - & 0.004 & 0.662 & $*$ & 0.175 \\
\hline $\begin{array}{l}\text { Talk to par- } \\
\text { ents about } \\
\text { politics }\end{array}$ & 0.020 & $* * *$ & 0.004 & 0.018 & $* * *$ & 0.005 & 1.511 & $* *$ & 0.146 \\
\hline $\begin{array}{l}\text { Parents have } \\
\text { voted }\end{array}$ & 0.006 & $\sim$ & 0.003 & 0.007 & $\sim$ & 0.004 & 6.483 & $* * *$ & 0.171 \\
\hline $\begin{array}{l}\text { Religious } \\
\text { Events: } \\
\text { never }\end{array}$ & 0.001 & - & 0.003 & 0.015 & $* * *$ & 0.003 & 0.613 & $* * *$ & 0.121 \\
\hline $\begin{array}{l}\text { Religious } \\
\text { Events }\end{array}$ & -0.001 & - & 0.002 & 0.005 & & 0.003 & 0.800 & $*$ & 0.088 \\
\hline $\begin{array}{l}\text { Religious } \\
\text { Events: } \\
\text { Frequent } \\
\text { (ref) }\end{array}$ & - & - & - & - & - & - & - & - & - \\
\hline $\begin{array}{l}\text { Member } \\
\text { of political } \\
\text { party: No }\end{array}$ & -0.165 & $* * *$ & 0.005 & -0.046 & $* * *$ & 0.005 & 0.544 & $*$ & 0.254 \\
\hline $\begin{array}{l}\text { Member } \\
\text { of political } \\
\text { party: Yes } \\
\text { (ref) }\end{array}$ & - & - & & - & - & - & - & - & - \\
\hline $\begin{array}{l}\text { Participate } \\
\text { Index }\end{array}$ & 0.261 & $* * *$ & 0.010 & 0.293 & $* * *$ & 0.011 & 5.598 & $* * *$ & 0.484 \\
\hline \multicolumn{10}{|c|}{ Contextual variables } \\
\hline Nordic & -0.011 & - & 0.010 & -0.013 & - & 0.030 & 0.929 & - & 0.485 \\
\hline Conservative & -0.009 & - & 0.009 & 0.015 & - & 0.029 & 0.541 & - & 0.399 \\
\hline Mediterranean & -0.010 & $\sim$ & 0.005 & 0.045 & $* *$ & 0.016 & 0.756 & - & 0.231 \\
\hline Liberal & 0.002 & - & 0.009 & -0.035 & - & 0.029 & 0.202 & $* * *$ & 0.307 \\
\hline $\begin{array}{l}\text { Post-socialist } \\
\text { (Ref) }\end{array}$ & & - & - & - & - & - & - & - & - \\
\hline $\begin{array}{l}\text { Human Dev. } \\
\text { Index }\end{array}$ & 0.069 & - & 0.072 & 0.399 & $\sim$ & 0.217 & 2992.917 & $* *$ & 2.684 \\
\hline $\begin{array}{l}\text { Corruptions } \\
\text { Per. Index } \\
\end{array}$ & 0.000 & - & 0.000 & -0.001 & - & 0.001 & 0.999 & - & 0.008 \\
\hline
\end{tabular}

$* * * p<0.001, * * p<0.01, * p<0.05, \sim p<0.1$ 
who never attend religious events are more likely to participate in protest action than young people who do attend religious events.

\section{Conclusion}

The political participation of young people varies significantly across Europe at both national and regional levels, confirming previous studies at a European cultural level (Kitanova 2019; Sloam 2016) and hypothesis 1. Our descriptive analyses identifies that there are distinct clustering of participation, views on democratic performance and political socialisation by welfare state region, representing age of democracy and local context including impact of the economic crisis. This study has identified that there are significant barriers to participation as identified in the literature (Hooghe and Marien 2013). Our regression models identify that young people from families with low parental social class are less likely to participate in voting, traditional forms of participation and protest action than those young people from families who high parental social class. Young people are more likely to participate in nonelectoral forms (traditional and protest action) than older people, and older people are more likely to vote (18-24 in sample), although, beta coefficients are small. Gender is not significant (apart from males for protest action), although in general confirms hypothesis 2 that participation is differentiated by demographics. Political socialisation of young people is an important factor towards increasing levels of participation confirming hypothesis 4 . Young people who are more interested in politics are more likely to participate, higher political knowledge is significantly linked to voting in national elections, however, young people with lower political knowledge are more likely to participate in protest action. Family influences such as talking with parents about politics and parents voting have significant positive effect on participation. Frequent attendance at religious events increases the likelihood of voting, however, young people who never attend religious events are more likely to participate in protest action. Political party membership and participation in various forms of civic engagement increases all forms of participation.

Young people who are more cynical are less likely to vote and more likely to participate in protest action. Lower trust in political institutions also increases protest action. Young people with positive views towards democracy are more likely to vote. However, there are higher levels of traditional participation, when young people have more negative views towards democratic systems and less satisfied with democracy. Therefore, the findings are mixed in confirming hypothesis 3: poor perceptions of democratic performance decrease participation, however confirm hypothesis 5 : that different predictors are significant between forms of participation. Traditional and protest action forms of participation are different from the voting in national elections. Voting is more 'universal' than the other forms of participation. Young people participating in traditional forms in general have stronger negative democratic barrier perceptions, but this provides an avenue to participate at a young age.

There are a number of limitations of this study; first, a single cohort only provides a snapshot in time (2012/13), a time of economic crisis and the sovereign debt crisis with stable economies in the north and economies struggling with austerity 
measures in the south clearly influencing the results. The case study approach is not nationally representative, therefore not fully comparable with the ESS or Eurobarometer surveys, nor comparison with adult populations (Sloam 2016). Also, we have only examined aggregate forms of participation, rather than the 20 individual types that were used to construct them. Nonetheless, our data represents an important historical era during which the immediate effects of the financial crisis were felt across Europe. In addition, through the questionnaire being input harmonised it is fully comparable between the research locations and is therefore superior to any other international comparison of youth political participation undertaken hitherto. 


\section{Appendix}

Table 3 Dependent variablelconstruction

\begin{tabular}{|c|c|c|}
\hline Questions & Variable & Cronbach alpha \\
\hline $\begin{array}{l}\text { There are different ways of being politically active. During the } \\
\text { last } 12 \text { months, how often have you done the following? } \\
\text { (never, once, twice, three times or more) } \\
\text { - Volunteered in an election campaign } \\
\text { - Contacted a politician or local councillor (e-mail/ } \\
\text { phone/SMS/letter/fax etc) } \\
\text { - Collected signatures } \\
\text { - Given a political speech } \\
\text { - Distributed leaflets with a political content }\end{array}$ & $\begin{array}{l}\text { Traditional } \\
\text { participation }\end{array}$ & $\begin{array}{l}\text { Alpha }=0.690, \\
\text { varies from } \\
0.529 \text { in western } \\
\text { Germany to } 0.810 \\
\text { in Hungary }\end{array}$ \\
\hline $\begin{array}{l}\text { There are different ways of being politically active. During the } \\
\text { last } 12 \text { months, how often have you done the following? } \\
\text { (never, once, twice, three times or more) } \\
\text { - Participated in a demonstration } \\
\text { - Participated in a strike } \\
\text { - Participated in a violent political event } \\
\text { - Occupied buildings or blocked streets/railways } \\
\text { - Participated in a 'flashmob' (a spontaneous demonstration } \\
\text { organised by social media) }\end{array}$ & & $\begin{array}{l}\text { Alpha }=0.621, \\
\text { varies from } \\
0.308 \text { in Finland } \\
\text { to } 0.795 \text { in Hun- } \\
\text { gary }\end{array}$ \\
\hline $\begin{array}{l}\text { Derived variable from; } \\
\text { Did you vote in the last [country] national election? } \\
\text { Could you tell me which of the following reasons best explain } \\
\text { why you did not vote? (excluding "I was not eligible") }\end{array}$ & oting & - \\
\hline
\end{tabular}


Table 4 Thematic clustering of independent|variables in the regression modelling

\begin{tabular}{|c|c|c|c|}
\hline Theme & Sub-theme & \multicolumn{2}{|c|}{ Variables used } \\
\hline \multirow[t]{19}{*}{ Barriers } & Demographics & \multicolumn{2}{|l|}{ Age } \\
\hline & & \multicolumn{2}{|l|}{ Gender } \\
\hline & & \multicolumn{2}{|c|}{ Parental Social Class } \\
\hline & Democratic & \multicolumn{2}{|c|}{ Trust towards core national institutions } \\
\hline & Performance & \multicolumn{2}{|l|}{ Cynicism } \\
\hline & & \multicolumn{2}{|c|}{ Politicians interested in Young People } \\
\hline & & \multicolumn{2}{|c|}{ Satisfaction with Democracy } \\
\hline & & \multicolumn{2}{|c|}{ Positive views towards a democratic system } \\
\hline & & \multirow[t]{2}{*}{ Efficacy } & External efficacy (Non Violent Efficacy) \\
\hline & & & External efficacy (Violent/Illegal Efficacy) \\
\hline & \multirow{9}{*}{$\begin{array}{l}\text { Political } \\
\text { Socialisation }\end{array}$} & \multirow[t]{3}{*}{ Individual } & Political Interest \\
\hline & & & Internal efficacy: Political Knowledge \\
\hline & & & $\begin{array}{l}\text { How much time to spend keeping yourself informed } \\
\text { about politics/current affairs (Inform) }\end{array}$ \\
\hline & & \multirow[t]{3}{*}{ Family } & Interest in politics of parents \\
\hline & & & Discuss political issues with parents \\
\hline & & & How often do parents vote in elections \\
\hline & & \multirow{3}{*}{$\begin{array}{l}\text { Other } \\
\text { institutions }\end{array}$} & Attendance at Religious Events \\
\hline & & & Member of political party \\
\hline & & & Participation Index \\
\hline \multirow[t]{3}{*}{ Contextual } & & \multicolumn{2}{|c|}{ Welfare State } \\
\hline & & \multicolumn{2}{|c|}{ Human Development Index } \\
\hline & & \multicolumn{2}{|c|}{ Corruption perceptions index } \\
\hline
\end{tabular}




\section{References}

Berger, B. (2009). Political theory, political science and the end of civic engagement. Perspectives on politics, 7(2), 335-350.

Childs, S. (2004). A British gender gap? Gender and political participation. The political quarterly, 75(4), $422-424$.

Coffé, H., \& Bolzendahl, C. (2010). Same game, different rules? Gender differences in political participation. Sex Roles, 62(5-6), 318-333.

Coppedge, M., Gerring, J., Altman, D., Bernhard, M., Fish, S., Hicken, A., \& Semetko, H. A. (2011). Conceptualizing and measuring democracy: a new approach. Perspectives on Politics, 9(2), 247-267.

Dalton, R., \& Wattenberg, M.P. (Eds.). (2000). Parties without partisans: political change in advanced industrial democracies. Oxford: Oxford University Press.

Djupe, P. A., \& Gilbert, C. P. (2002). The political voice of clergy. The Journal of Politics, 64(2), 596-609.

Ekman, J., \& Amnå, E. (2012). Political participation and civic engagement: towards a new typology. Human affairs, 22(3), 283-300.

Fieldhouse, E., Tranmer, M., \& Russell, A. (2007). Something about young people or something about elections? Electoral participation of young people in Europe: Evidence from a multilevel analysis of the European Social Survey. European Journal of Political Research, 46, 797-822.

Flanagan, C., \& Levine, P. (2010). Civic engagement and the transition to adulthood. The future of children, 20(1), 159-179.

Foweraker, J., \& Landman, T. (2002). Constitutional design and democratic performance. Democratization, 9(2), 43-66.

Fu, H., Mou, Y., Miller, M. J., \& Jalette, G. (2011). Reconsidering political cynicism and political involvement: a test of antecedents. American Communication Journal, 13(2), 44-61.

Furlong, A., \& Cartmel, F. (2012). Social change and political engagement among young people: generation and the 2009/2010 British election survey. Parliamentary Affairs, 65, 13-28.

Grimm, R., Pollock, G., \& Ellison, M. (2017). Eurosceptic youth, interest, trust and ideology. In B. Leruth, N. Startin \& S. Usherwood (Eds.), Routledge handbook of Euroscepticism. London: Routledge.

Henn, M., \& Foard, N. (2014). Social differentiation in young people's political participation: the impact of social and educational factors on youth political engagement in Britain. Journal of Youth Studies, 17(3), 360-380.

Hooghe, M., \& Marien, S. (2013). A comparative analysis of the relation between political trust and forms of political participation in Europe. European Societies, 15(1), 131-152.

Horvath, A., \& Paolini, G. (2014). Political participation and EU citizenship: perceptions and behaviors of young people. http://eacea.ec.europa.eu/youth/tools/documents/perception-behaviours.pdfl

Inglehart, R. (1977). The silent revolution. Changing values and political styles among western publics. Princeton: Princeton University Press.

Jahn, D., Düpont, N., \& Rachuj, M. (2018). Left-Right Party Ideology in 36 Countries (Greifswald Comparative Politics Working Paper No. 11). http://comparativepolitics.uni-greifswald.de/gcp/GCP-112018.pdf. Accessed 11 Dec 2019.

Jan, T., Charron, N., Dahlberg, S., Holmberg, S., Rothstein, B., Sundin, P., \& Svensson, R. (2013). The quality of government basic Dataset made from the quality of government Dataset (version 15. May 13]. Gothenburg: University od Gothenburg, The Quality of Government Institute. http://www.qog. pol.gu.se

Kaariainen, J., \& Lehtonen, H. (2006). The variety of social capital in welfare state regimes-a comparative study of 21 countries. European Societies, 8(1), 27-57.

Kimberlee, R.H. (2002). Why don't British young people vote at general elections? Journal of Youth Studies, 5(1), 86-98.

Kitanova, M. (2019). Youth political participation in the EU: evidence from a cross-national analysis. Journal of Youth Studies. https://doi.org/10.1080/13676261.2019.1636951.

Kostadinova, T., \& Power, T. (2007). Does democratization deepen participation? Voter turnout in the latin American and eastern European transitional democracies. Political Research Quarterly, 60, 363-377.

Li, Y., \& Marsh, D. (2008). New forms of political participation: searching for expert citizens and everyday makers. British Journal of Political Science, 38, 247-272.

Lijphart, A. (2012). Patterns of democracy: government forms and performance in thirty-six countries. Yale: University Press. 
LSE (2013). Youth participation in democratic life-final report, London school of economics. http:// www.lse.ac.uk/businessAndConsultancy/LSEEnterprise/pdf/YouthParticipationDemocraticLife.pdf. Accessed 1 Mar 2015.

Marien, S., Hooghe, M., \& Quintellier, E. (2010). Inequalities in non-institutionalized forms of political participation: a multi-level analysis of 25 countries. Political Studies, 58, 187-121.

Niemi, R. G., Craig, S.C., \& Mattei, F. (1991). Measuring internal political efficacy in the 1988 national election study. American Political Science Review, 85, 1407-1413.

Norris, P. (1999). Introduction: the growth of critical citizens? In Critical citizens: global support for democratic government (pp. 1-27).

Norris, P. (Ed.). (2001). Digital divide: civic engagement, information poverty, and the Internet worldwide. Cambridge: Cambridge University Press.

Norris, P. (2002). Democratic Phoenix: reinventing political activism. Cambridge: University Press.

Norris, P. (2003). Young people and political activism: From the politics of loyalties to the politics of choice? Council of Europe Symposium: Young People and democratic institutions: from disillusionment to participation, Strasbourg.

Norris, P. (2004). Young people and political activism: from the politics of loyalties to the politics of choice. Report for the Council of Europe Symposium: Young people and democratic institutions: from disillusionment to participation, Strasbourg, 27-28th November 2003.

Norris, P. (2011). Democratic deficit: critical citizens revisited. Cambridge: CUP.

Pearson-Merkowitz, S., \& Gimpel, J.G. (2009). Religion and political socialization. In C.E. Smidt, J.L. Guth \& L.A. Kellstedt (Eds.), The Oxford handbook of religion and American politics (pp. 164-190). Oxford: Oxford University Press.

Pew Research Center (2018). The age gap in religion around the world. https://www.pewforum.org/2018/ 06/13/how-religious-commitment-varies-by-country-among-people-of-all-ages/. Accessed 13 June 2018.

Pfanzelt, H., \& Spies, D.C. (2018). The gender gap in youth political participation: evidence from Germany. Political Research Quarterly. https://doi.org/10.1177/1065912918775249.

Pilkington, H., \& Pollock, G. (2015). "Politics are bollocks": youth, politics and activism in contemporary europe. In H. Pilkington \& G. Pollock (Eds.), Radical futures? Youth, politics and activism in contemporary Europe. Sociological Review Monograph Series. (pp. 1-35). Oxford: Wiley-Blackwell.

Politico (2019). European elections 2019: Voter turnout. https://www.politico.eu/interactive/votersturnout-in-the-european-elections/. Accessed 12 Dec 2019.

Pollock, G. (2018). Survey research and sensitivity to context: The MYPLACE project and its case study approach. In H. Pilkington, G. Pollock \& R. Franc (Eds.), Understanding youth participation across Europe: from survey to ethnography (pp. 19-36). Basingstoke: Palgrave.

Pollock, G., Brock, T., \& Ellison, M. (2015). Populism, ideology and contradiction. In H. Pilkington \& G. Pollock (Eds.), Radical futures? Youth, politics and activism in contemporary Europe. Sociological review monograph series. (pp. 141-166). Oxford: Wiley-Blackwell.

Pontes, A. I., Henn, M., \& Griffiths, M.D. (2017). Youth political (dis)engagement and the need for citizenship education: encouraging young people's civic and political participation through the curriculum. Education, Citizenship and Social Justice, 14(1), 3-21.

Sloam, J., \& Henn, M. (2019). Youthquake 2017. Palgrave Studies in Young People and Politics. https:// doi.org/10.1007/978-3-319-97469-9_3.

Stockemer, D. (2014). What drives unconventional political participation? A two level study. The Social Science Journal, 51(2), 201-211.

Stolle, D., Hooghe, M., \& Micheletti, M. (2005). Politics in the supermarket: political consumerism as a form of political participation. International Political Science Review, 26(3), 245-269.

Teorell, J., Torcal, M., \& Montero, J.R. (2007). Political participation: mapping the terrain. In Citizenship and involvement in European democracies: a comparative perspective (Vol. 17, pp. 334-357).

Touchton, M., \& Wampler, B. (2014). Improving social well-being through new democratic institutions. Comparative Political Studies, 47(10), 1442-1469.

Trechsel, A. H. (2007). Inclusiveness of old and new forms of citizens' electoral participation. Representation, 43(2), 111-121.

Verba, S., \& Nie, N.H. (1972). Participation in America: political democracy and social equality. New York: Harper \& Row.

Verba, S., Schlozman, K. L., \& Brady, H.E. (1995). Civic participation and the equity problem

Vromen, A. (2003). People try to put us down ... participatory citizenship of generation X. Australian Journal of Political Science, 38(1), 79-99.

Wattenberg, M.P. (2006). Is voting for young people? New York: Pearson Longman. 


\section{Author queries}

1 page 1

References in Abstract/Zusammenfassung are not permitted. Please replace.

2 page 2

Please include reference 'Sigel 1965 ' in the bibliography or remove the respective reference/references from the text.

\section{3 page 3}

Please insert a citation for reference 'Jahn et al. (2018)' into the main text. Alternatively you can delete the entry from the list of references or ask for it to be added as 'Further Reading'.

4 page 3

Please insert a citation for reference 'Jan et al. (2013)' into the main text. Alternatively you can delete the entry from the list of references or ask for it to be added as 'Further Reading'.

5 page 3

Please insert a citation for reference 'Kostadinova and Power (2007)' into the main text. Alternatively you can delete the entry from the list of references or ask for it to be added as 'Further Reading'.

\section{6 page 3}

Please insert a citation for reference 'Norris (2004)' into the main text. Alternatively you can delete the entry from the list of references or ask for it to be added as 'Further Reading'.

\section{7 page 3}

Please insert a citation for reference 'Pontes et al. (2017)' into the main text. Alternatively you can delete the entry from the list of references or ask for it to be added as 'Further Reading'.

8 page 3

Please check city and country for 'Ipsos'.

\section{page 3}

Please include reference 'Youth Partnership (2014)' in the bibliography or remove the respective reference/references from the text.

\section{0 page 3}

Please include reference 'Henn and Foard (2012)' in the bibliography or remove the respective reference/references from the text.

11 page 4 
Please verify reference 'Ekman and Amna 2012'. Spelling of author name differs.

12 page 4

The tables in the appendix have been renamed. Please check the adaptation in the captions and references: Appendix $\mathrm{A} \Rightarrow$ Table 3; Appendix $\mathrm{B} \Rightarrow$ Table 4.

13 page 4

Please include reference 'Sloam 2016' in the bibliography or remove the respective reference/references from the text.

14 page 4

Please include reference 'Eurobarometer (2013)' in the bibliography or remove the respective reference/references from the text.

15 page 5

Please include reference 'Inglehart and Norris 2003' in the bibliography or remove the respective reference/references from the text.

\section{6 page 5}

Please include reference 'Beauregard 2014' in the bibliography or remove the respective reference/references from the text.

17 page 5

Please include reference 'Milbrath and Goel 1977' in the bibliography or remove the respective reference/references from the text.

\section{8 page 5}

Please include reference 'Nie and Verba 1987' in the bibliography or remove the respective reference/references from the text.

19 page 5

Please include reference 'Rosenstone and Hansen 2002' in the bibliography or remove the respective reference/references from the text.

\section{0 page 6}

Please include reference 'Christensen and Laegreid 2003' in the bibliography or remove the respective reference/references from the text.

\section{1 page 6}

Please include reference 'Dermody et al. 2010' in the bibliography or remove the respective reference/references from the text.

\section{2 page 7}

Please include reference 'Hooghe 2004' in the bibliography or remove the respective reference/references from the text.

23 page 7 
Please include reference 'Lee et al. 2012' in the bibliography or remove the respective reference/references from the text.

24 page 10

Please provide the missing closing bracket for: ....and efficacy (both non-violent/legal and violent/illegal efficacy...

25 page 16 (figure 7)

The manuscript included two different versions of the caption of figure 7 . Please check.

\section{6 page 12}

Please provide the missing quotation marks at the end of: ....and 'Participated in a ...

27 page 19 (table 1$)$

Please verify the layout of table 1 by using the PDF of the preliminary print version of the article. The file is accessible under 'Home' (house symbol) under the section 'Download File'.

28 page 16

Please include reference 'Esping-Andersen 1990' in the bibliography or remove the respective reference/references from the text.

29 page 16

Please verify reference 'Kääriäinen and Lehtonen 2006'. Spelling of author name differs.

30 page 20 (table 2_1)

Please verify the layout of table 2 . A dash ( - ) was inserted into deliberately empty cells. Please confirm.

31 page 24 (table 3 )

Please verify the layout of table 3 . A dash ( - ) was inserted into deliberately empty cells. Please confirm.

32 page 25 (table 4 )

The structure of table 4 was changed. Please check and make any necessary corrections.

33 page 26

In this citation the value for access date is missing. Please provide the value. 